\title{
Kajian Tentang Efek Pemberian Nutrisi Kedelai (Glicine max) Terhadap Penurunan Kadar Kolesterol Total Pada Menopause
}

\section{Study About the Effects of Soy (Glicine max) Intake Giving to Reduce Total Cholesterol level on Menopause}

Febri Endra Budi Setyawan ${ }^{1}$

${ }^{1}$ Staf Pendidik Fakultas Kedokteran Universitas Muhammadiyah Malang

\begin{abstract}
Abstrak
Latar belakang: Kadar kolesterol darah yang meningkat merupakan resiko terjadinya arterosklerosis pada penyakit pada jantung koroner. Wanita menopause mempunyai kadar estrogen yang sangat rendah, sehingga menyebabkan peningkatan faktor resiko profil lipid. Kedelai memiliki kadar protein yang tinggi, yaitu rata-rata 35\%, bahkan pada varietas unggul dapat mencapai 40-44\%. Protein kedelai memiliki susunan asam amino esensial lengkap, serta daya cerna yang sangat baik. Kandungan asam amino pada kedelai terutama adalah metionin dan sistein, sedangkan kandungan lisin dan treonin sangat tinggi. Lemak kedelai mengandung asam lemak esensial yang cukup, yaitu asam linoleat (omega-6) serta asam linolenat (omega-3) sehingga memberikan pengaruh yang sangat berarti bagi kesehatan, khususnya dalam kaitannya dengan pengendalian kolesterol dan penyakit kolesterol dan penyakit kardiovaskuler. Mekanisme penurunan kolesterol oleh kedelai disebabkan oleh isoflavon yang mempunyai sifat estrogenik, sehingga terjadi penurunan LDL, TG dan kenaikan dari HDL dan akhirnnya terjadi penurunan kadar kolesterol total dalam darah. Ada berbagai macam faktor yang mempengaruhi asupan kedelai terhadap penurunan kolesterol total. Faktor-faktor yang mempengaruhi asupan kedelai dalam penurunan kolesterol total adalah bentuk dan jenis isoflavon, kadar asupan isoflavon, waktu penelitian, gender dari subjek, kadar lipid serta status dari menopause.
\end{abstract}

Kata kunci: Kadar kolesterol, kedelai, menopouse 
Abstract

Background: Increased blood cholesterol levels are a risk of arterosclerosis in coronary heart disease. Menopausal women have very low estrogen levels, thus leading to an increase in lipid profile risk factors. Soybean has high protein content, which is average 35\%, even at high yielding varieties can reach 40-44\%. Soy protein has a complete array of essential amino acids, as well as excellent digestibility. Amino acid content in soybean is mainly methionine and cysteine, while the lysine and threonine content is very high. Soy fat contains sufficient essential fatty acids, linoleic acid (omega-6) and linolenic acid (omega-3) to give a significant effect on health, especially in relation to cholesterol control and cholesterol disease and cardiovascular disease. The mechanism of lowering cholesterol by soybeans is caused by isoflavones that have estrogenic properties, resulting in a decrease in LDL, TG and an increase in HDL and ultimately a decrease in total cholesterol levels in the blood. There are various factors that affect the intake of soybean to decrease total cholesterol. Factors affecting soy intake in total cholesterol reduction are the form and type of isoflavones, isoflavone intake levels, research time, gender of the subject, lipid levels and status of menopause

Key words: cholesterol levels, soybean, menopausal women

\section{PENDAHULUAN}

Populasi wanita menopause diatas 45 tahun di sebelas negara di Asia tenggara pada tahun 2010 ini sebanyak 1 miliar. Diperkirakan di tahun 2030 nanti ada 1,2 miliar wanita yang berusia diatas 45 tahun. Jumlah wanita menopause yang meningkat mengakibatkan meningkatnya angka kejadian penyakit jantung koroner pada wanita. Wanita menopause mempunyai kadar estrogen yang sangat rendah, sehingga menyebabkan peningkatan faktor resiko profil lipid. Kadar kolesterol darah yang meningkat merupakan resiko terjadinya arterosklerosis pada penyakit pada jantung koroner (Aso T, 1999).

Pada wanita menopause, sekresi hormon estrogen turun sebagai akibat atrofi dari ovarium. Setelah menopause atau paska ovarektomi cenderung terjadi peningkatan kadar kolesterol total, kolesterol Low Density Lipoprotein (LDL), sementara reseptor untuk LDL menjadi berkurang. Estrogen berperan dalam keseimbangan kolesterol LDL dan kolesterol High Density lipoprotein (HDL) melalui peningkatan kolesterol HDL dan penurunkan kolesterol LDL. Pemberian estrogen peroral juga dapat menurunkan kolesterol total dan melindungi LDL dari oksidasi. Peningkatan kolesterol total dan kolesterol LDL dan penurunan kolesterol HDL serta peningkatan rasio LDL/HDL merupakan faktor risiko terjadinya aterosklerosis dengan segala akibatnya (Supriyanto, 2006).

Salah satu langkah atau solusi yang dilakukan saat ini dalam menghadapi keluhan pada saat menopause adalah dengan melakukan terapi sulih hormon. Terapi ini dilakukan dengan cara memasukkan hormon estrogen kepada wanita yang mengalami menopause. Akan tetapi, jika diberikan berlebihan terapi ini memiliki efek samping yang tidak ringan. Efek samping tersebut adalah stroke, tromboemboli vena, kanker payudara dan kanker leher rahim (Practice Committee of The American Society for Reproductive Medicine, 2008).

Untuk menghindari efek samping dari penggunaan terapi sulih hormon, diperlukan suatu alternatif pengganti yang lebih aman dalam menjaga kesehatan pada saat menopause. Pemanfaatan bahan-bahan alami yang dapat menjadi salah satu alternatif pengganti TSH. Salah satu bahan alami terssebut yaitu fitoestrogen. Fitoesteogen berasal dari kata fito- yang berarti tanaman dan estrogen. Fitoestrogen merupakan kumpulan senyawa alami dari tanaman jenis polong-polongan yang mempunyai aktifitas biologis seperti estrogen. Tanaman jenis polongpolongan yang menjadi salah satu jenis makanan terpopuler di dunia mudah diperoleh yaitu tanaman yang berasal dari kacang kedelai (Koswara, 2009).

Senyawa fitoestrogen yang banyak terdapat pada kedelai adalah isoflavon. Isoflavon terbukti dapat berikatan $\mathrm{dg}$ reseptor esterogen secara allosterik dari hormon wanita yaitu estrogen. Estrogen berikatan dengan reseptor estrogen sebagai bagian dari aktivitas hormonal sehingga menyebabkan serangkaian reaksi yang menguntungkan tubuh. Pada saat kadar hormon estrogen menurun, akan terdapat banyak kelebihan reseptor estrogen yang tidak terikat. Jika tubuh mengkonsumsi produk-produk kedelai, maka akan tejadi pengaruh pengikatan isoflavon dengan reseptor estrogen yang menghasilkan efek menguntungkan sehingga mengurangi simptom menopause (Koswara, 2009). 
Survei di Jepang yang dilakukan oleh Suzuki tahun 1998 menunjukkan bahwa rendahnya angka kematian akibat jantung koroner, kanker payudara, kanker rahim, dan arterosklerosis dipengaruhi oleh tingginya tingkat konsumsi makanan asal kedelai, seperti tahu, natto, misso dan susu kedelai. Hal tersebut diduga oleh peran isoflavon kedelai yaitu genistein, daidzein dan glisetein, yang memiliki aktifitas biologis sebagai fitoesterogen, antioksidan dan antimutagen (Astawan,2009).

Mengingat manfaat dari sari kedelai yang mengandung isoflavon sangat berguna untuk mengatasi masalah wanita dengan menopause, maka penulis tertarik untuk mengkaji tentang efek pemberian nutrisi kedelai (Glycine max) terhadap kadar kolesterol total pada menopause.

\section{Menopause}

Periode dimana siklus berhenti dan hormonhormon kelamin wanita menghilang dengan cepat sampai hampir tidak ada disebut menopause. Penyebab menopause adalah lenyapnya semua folicle dan produksi esterogen ovarium (Murray et al, 2009). Sepanjang kehidupan seksual seorang wanita kira-kira 400 folikel primordial tumbuh menjadi folikel vesikuler dan berovulasi, sementara beratus-ratus dari ribuan ovum bergenerasi. Pada usia 45 tahun hanya tinggal beberapa folikel primordial yang akan dirangsang oleh Folikel Stimulating Hormon (FSH) dan Luteinizing Hormon (LH) dan produksi estrogen dari ovarium berkurang sewaktu jumlah folikel primordial mencapai nol (Guyton, 2006).

Menopause merupakan suatu bagian dari proses menua yang ireversibel yang melibatkan sistem reproduksi wanita. Ketika produk estrogen turun dibawah nilai kritis, estrogen tidak lagi menghambat produksi lonjakan produksi FSH dan LH, juga tidak dapat menahan lonjakan LH dan FSH ovulasi untuk menimbulkan siklus ovulasi. FSH dan LH (terutama FSH) diproduksi dalam jumlah dibawah nilai kritis untuk jangka waktu yang singkat sesudah menopause tetapi setelah beberapa tahun ketika folikel primordial yang tersisa menjadi atretik, produksi oleh ovarium turun menjadi hampir nol (Guyton, 2006).

Wanita post menopause mengalami gangguan pada vogina akibat gejala penurunan aliran darah vagina dan sekresi, hialinisasi kolagen, fragmentasi elastin, dan proliferasi jaringan ikat vagina. Cairan vagina, yang merupakan asam sebelum menopause, menjadi lebih netral, memfasilitasi organisme enterik berproliferasi yang dikaitkan dengan infeksi saluran kemih (Grady, 2006).

Perempuan dalam transisi menopause dilaporkan mempunyai berbagai gejala, termasuk gejala, inkontinensia, sulit tidur, disfungsi seksual, depresi, cemas, suasana hati labil, kehilangan memori, kelelahan, sakit kepala, sendi sakit, dan perubahan berat badan (Grady, 2006). Gejala di vagina (termasuk kering, rasa tidak nyaman, gatal, dan dispareunia) yang dilaporkan oleh sekitar 30 perempuan pada awal pasca menopause (Nelson, 2005) dan sampai $47 \%$ dari perempuan selama paska menopause (Dennerstein, 2000). Tidak seperti Hot flushes, gejala di vagina umumnya gejala menetap atau memburuk dengan penuaan (Grady, 2006). Gejala urologik (termasuk urgensi, frekuensi, disuria, dan inkontinensia) tidak selalu berkorelasi dengan transisi menopause (Dennerstein, 2000).

Flushes adalah perasaan tiba-tiba menjadi hangat yang umumnya pada wajah, leher, dan dada. Durasinya tergantung variabel (rata-rata 4 menit). Hal ini sering disertai dengan keringat yang banyak dan diikuti oleh merinding. Prevalensi hot flushes maksimal dalam transisi menopause terlambat, terjadi pada sekitar 65\% dari wanita menopause (Gold, 2000). Pada prevalensi yang nyata memberikan hasil yang bervariasi, tergantung pada definisi dari flushing dan populasi yang diteliti. Di Amerika Serikat, hot flushes lebih sering terjadi pada wanita hitam dan wanita Latin dan sering pada wanita Cina dan Jepang dari pada wanita kulit putih (Avis, 2001). Merokok meningkatkan kemungkinan flushing (Gold, 2000). Faktor lainnya termasuk pembedahan saat menopause, aktivitas fisik, indeks massa tubuh, konsumsi alkohol, dan status sosial ekonomi telah konsisten dikaitkan dengan bot flushes (Nelson, 2005).

\section{Estrogen, Fitoestrogen, dan Isoflavon}

Esterogen adalah hormon steroid C18 yang berasal dari 17- ketosteroidandrostenedion yang dibentuk oleh ovarium, plasenta, korteks adrenal, dan sel interstitial leydig dalam testis. Hormon esterogenik bertanggung jawab untuk perkembangan ciri-ciri seksual wanita. Estrogen juga meningkatkan perkembangan mukosa uterus, proses fertilisasi, dan lain-lain (Despopoulos, 2000).

Fitoestrogen merupakan substansi atau metabolit tanaman yang menginduksi respon biologi pada vetebrata, menimbulkan aktivitas yang mirip estrogen atau dapat memodulasi aksi estrogen endogen melalui ikatannya dengan RE (Reseptor Estrogen). Hal ini disebabkan karena fitoestrogen mempunyai struktur kimia yang mirip dengan hormon estrogen manusia, sehingga 
mampu berikatan dengan RE dan berkompetisi dengan estrogen endogen (Harborn

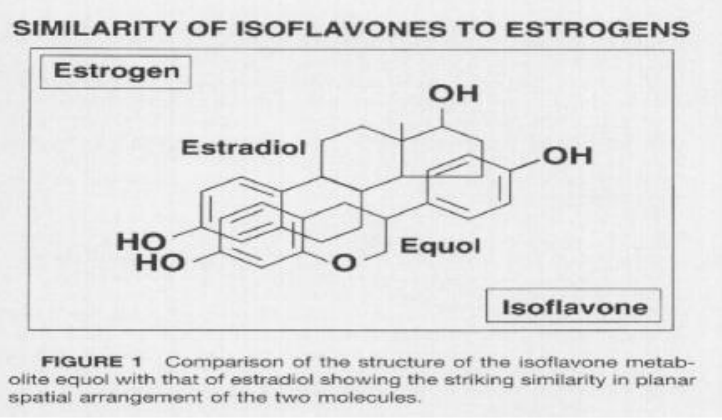

Gambar 1.

Dietary Isoflavones: Biological Effects And Relevance To Human Health (Setchell, 1999)

Aksi nuklear spesifik estrogen ditentukan oleh struktur hormon, subtipe atau isoform dari reseptor estrogen yang terlibat, karakteristik promotor gen target, serta keseimbangan koaktivator dan kompresor yang memodulasi respon transkripsional terakhir menuju kompleks dari estrogen dan reseptor estrogen. Ada dua subtipe reseptor estrogen dan beberapa isoform dan variasi dari masing-masing subtype yaitu $\mathrm{RE} \alpha$ dan RE $\beta$. Kedua subtipe reseptor berbeda dalam struktur, dan gen encoding kedua subtipe ada pada kromosom yang berbeda. Gen reseptor estrogen $\alpha$ telah dipetakan ke lengan panjang kromosom 6, sedangkan reseptor estrogen gen terletak pada band q22-24 kromosom 14 (Gruber, 2002). Distribusi dari reseptor estrogen $\alpha$ dan reseptor estrogen $\beta$ pada jaringan berbeda meskipun ada beberapa tumpang tindih. Sel granulosa dan spermatid sebagian besar mengandung reseptor estrogen $\beta$, dan subtipe ini ada dalam beberapa jaringan target nonklasik, termasuk ginjal, mukosa usus, parenkim paru-paru, sumsum tulang, tulang, otak, sel-sel endotel, dan kelenjar prostat. Sebaliknya, endometrium, kanker sel payudara, dan stroma ovarium sebagian besar mengandung reseptor estrogen $\alpha$ (Enmark et al, 1997).

Sebagian besar fitoestrogen termasuk dalam grup flavanoid, yaitu kelompok tanaman yang mengandung gugus fenolik. Flavanoid terdapat pada beberapa tanaman dan diperkirakan menyusun 7\% dari berat keringnya. Berbasarkan struktur kimianya, fitoestrogen dibagi menjadi 3 kelas, yaitu: isoflavanoid, koumestan dan lignan. Dalam bahan makanan isoflavanoid yang banyak ditemukan, dengan komponen utamanya daidzein dan genistaein (Harborn,2000).

Aktivitas mirip estrogen fitoestrogen disebabkan oleh karena fitoestrogen mempunyai 2 gugus $\mathrm{OH} /$ hidroksil yang berjarak 11,0 - 11,5 pada intinya yang sama persis dengan estrogen endogen. Jarak inilah yang disepakati sebagai struktur pokok suatu subtrat agar mempunyai efek estrogenik dan mempunyai afinitas tertentu terhadap RE (Nilson, 2000).

Ada empat bentuk isoflavon pada kedelai, yaitu: (1) bentuk aglikon (bentuk bebas): genistein, daidzein, dan glisitein, (2) bentuk glikosida: genistin, daidzin, dan glisetin,(3) bentuk asetilglikosida: 6-0-asetilgenistin, 6-0-asetildaidzin, dan 6-0-asetilglisetin, (4) bentuk maloglikosida: 60-malogenistin, 6-0-malodaidzin, dan 6-0maloglisetin. Isoflavon pada olahan kedelai non fermentasi umumnya berada dalam bentuk glikosida, yaitu $64 \%$ genistin, 23\% daidzin, dan $13 \%$ glisetin. Pada produk fermentasi kedelai seperti tempe dan miso, isoflavon umumnya berada dalam bentuk bebas (Astawan, 2009).

Isoflavon mempunyai beberapa manfaat bagi tubuh kita diantaranya menurunkan kadar kolesterol tubuh, kardioprotektif, meningkatkan densitas tulang, menurunkan tekanan intraokular, menurunkan keluhan, meningkatkan turgor kulit, memproduksi kolagen kulit, mengurangi keriput, menipiskan dan menghaluskan kulit, anti hipertensi, anti oksidan, anti kanker (Gruber, 2002), serta berpengaruh kepada kesuburan (Astawan, 2009).

Isoflavon dapat menurunkan kadar kolesterol darah karena isoflavon mempunyai sifat estrogenik dan antioksidan. Sebagai estrogenik, isoflavon menurunkan kolesterol dengan cara meningkatkan HDL, menurunkan LDL dan TG dalam darah, dan meningkatkan reseptor LDL di hati (Gruber, 2002; Adam, 2006). Sebagai antioksidan isoflavon mencegah oksidasi dari LDL (Yousef, 2004). Isoflavon juga dapat mencegah osteoporosis dengan cara mempengaruhi metabolisme tulang. Isoflavon merangsang aktifitas ploriferasi dan diferensiasi sel osteoblas sehingga mengambah densitas tulang (Gruber, 2002).

Isoflavon juga dipercaya sebagai anti kanker. Terdapat beberapa komponen dalam kedelai yang dipercaya mempunyai sifat anti kanker. Senyawa tersebut antara lain: inhibitor protease, phitat, saponin, phitosterol, asam lemak omega-3 dan isoflavon. Diantara anti kanker tersebut, perhatian terbesar ditunjukan terhadap 
isoflavon. Mekanisme yang banyak diketahui sebagai anti kanker dari isoflavon adalah aktivitas anti estrogen, menghambat aktivitas enzim penyebab kanker, aktivitas antioksidan dan meningkatkan fungsi kekebalan sel. Studi epidemilogi dan laboratorium telah menunjukkan bahwa konsumsi kedelai dapat mengurangi resiko perkembangan beberapa jenis kanker, antara lain kanker payudara, prostat dan kanker kolon (Koswara, 2009).

Dalam penelitian lain, isoflavon yang mirip dengan estrogen diperkirakan memiliki tindakan neuroprotektif. Dalam jaringan otak dari tikus dewasa, estrogen menginduksi sinaptik dan remodeling dendritik dan menyebabkan aktivasi sel glia. Dalam neuron di hipokampus, estrogen meningkatkan densitas reseptor N-metil-D-aspartate dan meningkatkan sensitivitas saraf (Gruber, $2002)$.

Pada masa perimenopause, estrogen juga menurunkan keluhan mood yang berfluktuasi. Pada mata, isoflavon menurunkan tekanan intraokular. Salah satu sifat isoflavon sebagai fitoestrogen adalah vasodilator sehingga bisa digunakan untuk terapi antihipertensi serta bersifat kardioprotektif. Pada topikal, estrogen juga meningkatkan turgor kulit, memproduksi kolagen kulit, mengurangi keriput, menipiskan dan menghaluskan kulit (Gruber, 2002).

Beberapa penelitian menemukan efek samping dari konsumsi kedelai dan olahannya namun efeknya minimal. Ada beberapa studi yang mendata hanya terjadi gangguan gastrointestinal. Sebuah studi meta analisis mengatakan bahwa, asupan kedelai yang tinggi dan berlebihan akan menimbulkan efek pada kelenjar tiroid, kelenjar payudara, serta endometrium. Dosis harian yang dianjurkan adalah 50-150 miligram (Cassidy, 2006).

Kontraindikasi dari isoflavon diantaranya adalah penderita hipotiroid, gangguan pembekuan darah, kanker payudara dan endometrium pada menopause serta penderita infertil. Isoflavon mempunyai efek samping hipotiroid, karena isoflavon mempengaruhi fungsi tiroid dan mengganggu penyerapan hormon tiroid sintetik, sehingga kontraindikasi dari isoflavon salah satunya adalah penderita hipotiroid Kekurangan yodium sangat meningkatkan efek antitiroid isoflavon, sedangkan suplemen yodium adalah pelindungnya (Cassidy, 2006). Kontraindikasi lain isoflavon adalah ganggguan pembekuan darah. Asupan isoflavon dalam jumlah yang panjang dapat meningkatkan faktor koagulasi, sehingga bisa meningkatkan resiko tromboemboli (Gruber, 2002). Isoflavon mecegah terjadinya kanker karena isoflavon mengandung antioksidan. Tetapi isoflavon meningkatkan jumlah sel pada sel kanker payudara dan sel kanker endometrium karena sel payudara dan sel endometrium dipengaruhi oleh estrogen endogen (Koswara, 2006).

Asupan isoflavon mengubah kepadatan payudara dan endometrium pada postmenopause wanita, tetapi dapat menyebabkan sedikit peningkatan kepadatan payudara pada premenopause perempuan. Hal ini menjelaskan bahwa pada saat premenopause (keadaan kadar estrogen endogen yang tinggi), isoflavon bersifat antiestrogenik sehingga menurunkan kadar estrogen endogen. Sedangkan pada wanita postmenopause (keadaan kadar estrogen rendah sampai habis), estrogen bersifat estrogenik mengantikan estrogen endogen (Koswara, 2006).

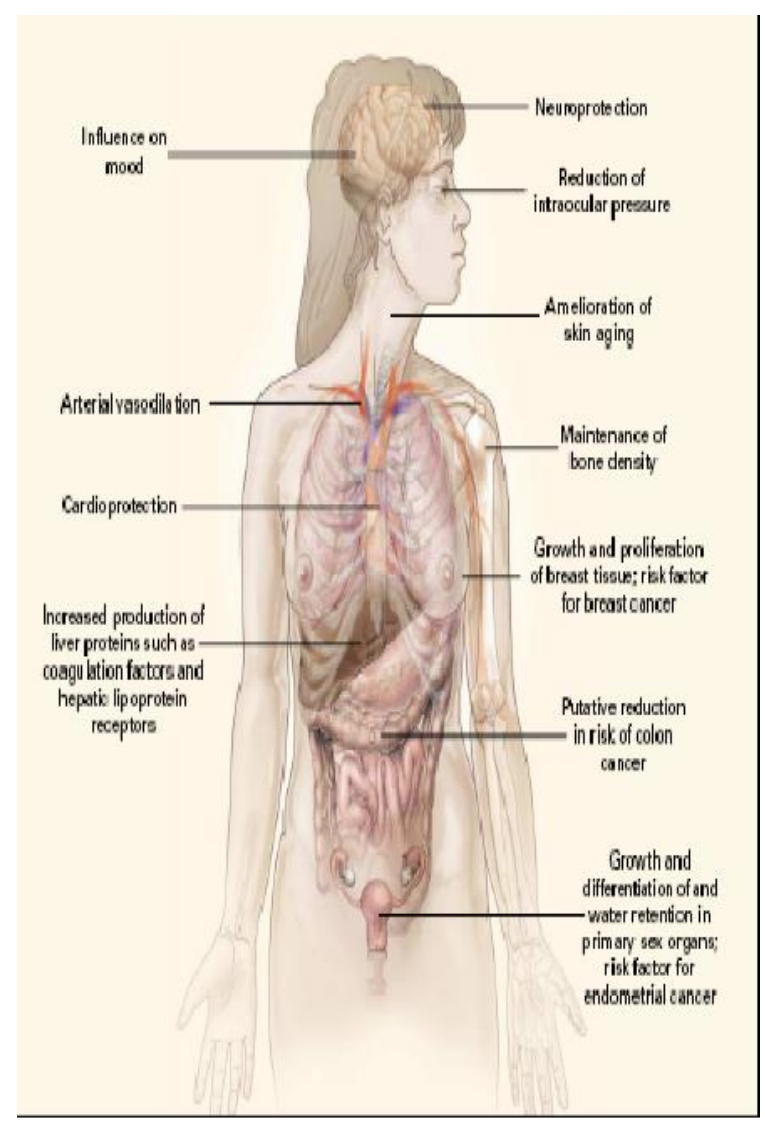

Gambar 2.Beberapa Aksi dari Isoflavon (Gruber, 2002)

\section{Kolesterol, Lipoprotein, dan Dislipidemia}

Kolesterol sangat larut dalam air, dan mampu membentuk ester dengan asam lemak.sebenarnya, hampir 70\% kolesterol dalam lipoprotein plasma dalam bentuk kolesterol ester (Guyton, 2006). Kolesterol berkonjugasi dengan 
zat lain untuk membentuk garam empedu, yang membantu pencernaan dan absorbsi lemak. Sebagian kecil kolesterol dipakai oleh kelenjar adrenal untuk membentuk hormon adrenokortikal, di ovarium membentuk progesteron dan estrogen, dan di testis membentuk testosteron. Sejumlah besar kolesterol diendapkan dalam lapisan korneum kulit. Hal ini bersama dengan lemak lainnya, membuat kulit lebih persisten terhadap absorbsi zat yang larut dalam air dan juga kerja dari berbagai zat kimia, karena kolesterol dan zat lain sangat tidak berdaya zat-zat seperti asam lemak dan berbagai pelarut, yang bila tidak mudah menembus tubuh. Fungsi lain dari kolesterol yaitu membantu mencegah evaporasi (Guyton, 2006).

Sumber utama kolesterol dalam makanan adalah kuning telur dan daging, terutama daging merah dan hati. Karena kolesterol tidak disintesis oleh tumbuhan, sayuran dan buah berperan penting dalam diet rendah kolesterol. Walaupun sebagian besar jaringan hewan dapat mensintesis kolesterol yang diperlukan lebih besar dari kolesterol yang diperoleh dari makanan, tempat utama pembentukan kolesterol adalah hati dan usus (Marks, 2000).

Dalam darah kita ditemukan tiga jenis lipid yaitu kolesterol, trigliserida, dan fosfolipid. Oleh karena sifat lipid yang susah larut dalam lemak, maka perlu dibuat bentuk yang terlarut. Untuk itu dibutuhkan suatu zat pelarut yaitu suatu protein yang dikenal dengan nama apolipoprotein atau apoprotein. Pada saat ini dikenal Sembilan jenis apoprotein yang diberi nama secara alfabetis yaitu Apo A, Apo B, Apo C, dan Apo E. Senyawa lipid dengan apoprotein dikenal dengan nama lipoprotein. Setiap jenis lipoprotein mempunyai apoprotein sendiri (Adam, 2006).

Setiap lipoprotein akan terdiri atas kolesterol (bebas atau ester), trigliserida, fosfolipid, dan apoprotein. Lipoprotein berbentuk sferik dan mempunyai inti trigliserida dan kolesterol ester dan dikelilingi oleh fosfolipid dan sedikit kolesterol bebas. Apoprotein ditemukan di permukaan lipoprotein.

Ada empat kelompok utama lipoprotein yang diketahui mempunyai makna yang penting secara fisiologis yaitu:

1. Kilomikron. Kilomikron bertugas mengangkut lipid yang terbentuk dari pencernaan dan penyerapan. Kilomikron ini berasal dari penyerapan triasilgliserol (trigliserida) dalam usus. Triasilgliserol merupakan simpanan lipid yang utama dalam jaringan adipose.
2. Lipoprotein dengan densitas yang sangat rendah atau very low density lipoprotein (VLDL atau pre-B-lipoprotein). VLDL berasal dari hati untuk mengeluarkan triasilgliserol dan bertugas mengangkut triasilgliserol dari hati.

3. Lipoprotein dengan densitas rendah atau low density lipoprotein (LDL atau B-lipoprotein). LDL merupakan lipoprotein yang yang kaya akan kolesterol serta terbentuk dari metabolisme VLDL. Protein utama yang membentuk LDL adalah Apo-B (apolipoprotein-B).

4. Lipoprotein dengan densitas tinggi atau high density lipoprotein (HDL). HDL merupakan lipoprotein yang kaya akan kolesterol tetapi terlibat dalam pengeluaran kolesterol dari jaringan serta dalam metabolisme jenis lipoprotein lainnya. HDL mencegah kolesterol mengendap di arteri dan melindungi pembuluh darah dari proses aterosklerosis (terbentuknya plak pada dinding pembuluh darah). Protein utama yang membentuk HDL adalah Apo-A. (Murray, 2009)

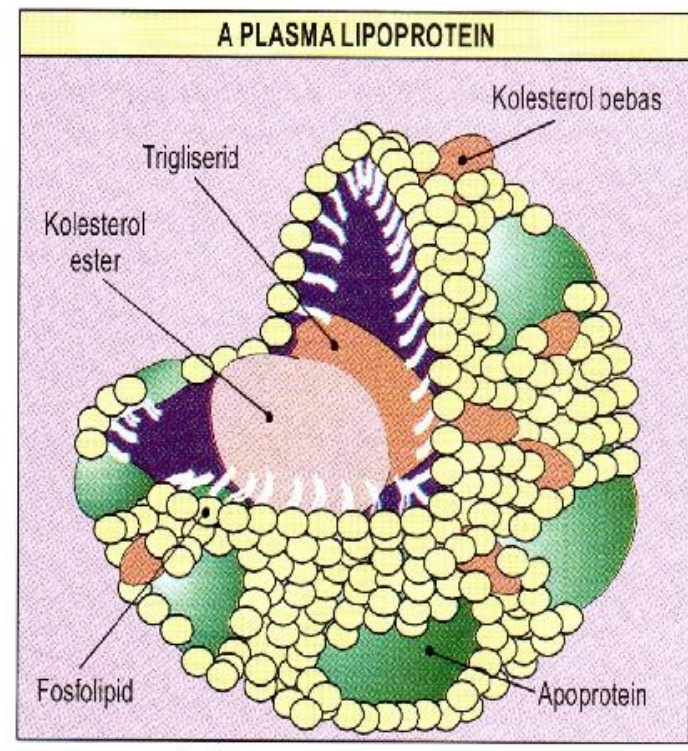

Gambar 3. Struktur Lipoprotein(Murray, 2009)

Dislipidemia adalah kelainan metabolisme lipid yang ditandai dengan peningkatan maupun penurunan fraksi lipid dalam plasma. Beberapa kelainan fraksi lipid utama adalah kenaikan kadar kolesterol total, kolesterol LDL, trigliserida, serta penurunan kolestrol HDL. Berbagai perubahan profil lipid tersebut saling terkait satu dengan yang lain. Dislipidemia merupakan faktor resiko utama 
penyakit aterosklerosis dan penyakit jantung koroner. Dislipidemia adalah salah satu komponen dalam trias sindrom metabolik selain diabetes dan hipertensi (Pramono, 2009).

\section{Hubungan Asupan Kedelai dengan Penurunan Kadar Kolesterol Total}

Bukti-bukti hasil penelitian menunjukkan bahwa suplementasi diet dengan protein kedelai akan menurunkan kolesterol darah dan mengurangi penyakit kronis pada populasi di Barat. Hal lain yang menonjol adalah penurunan kadar kolesterol oleh suplementasi protein kedelai tersebut sama dengan yang disebabkan oleh obat-obat penurun kolesterol yang diproduksi secara sintetik, serta jumlah protein kedelai yang diperlukan cukup rendah. Terapi diet (terapi melalui pengaturan makanan) menjadi lebih efektif jika menggunakan protein kedelai dibandingkan jika hanya menggunakan makanan rendah lemak saja dalam mencegah penyakit jantung koroner. Ini dikarenakan isoflafvon meningkatkan HDL dan menurunkan kolesterol total, LDL dan TG (Koswara, 2009).

Survei di Jepang yang dilakukan oleh Suzuki tahun 1998 menunjukkan bahwa rendahnya angka kematian akibat jantung koroner, kanker payudara, kanker rahim, dan arterosklerosis dipengaruhi oleh tingginya tingkat konsumsi makanan asal kedelai, seperti tahu, natto, misso dan susu kedelai. Hal tersebut diduga oleh peran isoflavon kedelai yaitu genistein, daidzein dan glisetein, yang memiliki aktifitas biologis sebagai fitoesterogen, antioksidan dan antimutagen (Astawan,2009).

Secara umum isoflavon akan meningkatkan HDL, menurunkan LDL dan TG dalam darah dengan mekanisme yang masih kotroversial. Dalam hati, isoflavon berikatan dengan RE, lalu meningkatkan densitas dan jumlah reseptor LDL melalui mekanisme up-reguation. Sehingga ambilan LDL di plasma oleh hati meningkat. LDL yang sebagian besar mengandung sebagian besar kolesterol darah,akan menurunkan fraksi kolesterol total dalam darah. Isoflavon juga membantu transpor LDL ke jaringan steoidogenik seperti di kelenjar adrenal, testis, dan ovarium. Setelah mengikat pada reseptor estrogen di lipoprotein, kolesterol diserap oleh sel-sel steroidogenik lalu disimpan dan dipindahkan ke tempat sintesis steroid. (Gruber, 2002).

Mekanisme lain adalah dengan meningkatkan HDL. Peningkatan HDL oleh isoflavon, diduga dengan cara isoflavon yang berikatan dengan RE di hati akan meningkaatkan produksi HDL nascent. HDL nascent yang juga berasal dari usus halus, mempunyai bentuk gepeng dan mengandung apoprotein A1. HDL nascent akan mendekati makrofag untuk mengambil kolesterol yang tersimpan di makrofag. Setelah mengambil kolesterol di makrofag, HDL nascent berubah menjadi remmant HDL dewasa yang berbentuk bulat. Agar dapat diambil oleh HDL nascent, kolesterol di bagian dalam makrofag harus dibawa kepermukaan membran sel makrofag oleh suatu transporter yang disebut adenosine triphosphate-binding cassette transporter-1 atau disingkat ABC-1 (Adam, 2006).

Setelah mengambil kolesterol bebas dari sel makrofag, kolesterol bebas dari sel makrofag, kolesterol bebas akan diesterifikasi menjadi kolesterol ester oleh enzim lecithin cholesterol acetltransferase (LCAT). Selanjutnya sebagian kolesterol ester yang dibawa HDL akan mengambil dua jalur. Jalur pertama ialah ke hati dan ditagkap oleh scavenger reseptor class B type 1 (SR-B1). Jalur kedua adalah kolesterol ester dalam HDL akan dipertukarkan dengan trigliserida dan VLDL dan IDL dengan bantuan cholesterol ester transfer protein (CETP). Dengan demikian fungsi HDL sebagai "penyerap" kolesterol dari makrofag mempunyai dua jalur yaitu langsung ke hati dan tidak langsung melalui VLDL dan IDL untuk membawa kolesterol kembali ke hati (Adam, 2006).

Selain bersifat estrogenik, isoflavon juga bersifat sebagai antioksidan. Dari beberapa penelitian menunjukkan bahwa asupan isoflavon kedelai dapat menurunkan Thiobarbitorik Acid Reactive Subtance (TBARS). TBARS adalah sebuah radikal yang menyebabkan terjadinya mutagenesis, carsiogenesis sampai kematian sel. Penelitian lain menyebutkan bahwa asupan isoflavon mencengah reaksi hidrogen peroksida dengan menyumbangkan atom hidrogen ke radikal bebas, sehingga radikal bebas tidak jadi terbentuk. Ini sangat bermanfaat pada saat kadar LDL yang berlebihan di dalam plasma, sebagian besar LDL akan mengalami oksidasi lalu dimakan oleh makrofag menjadi foam cell. Antioksidan isoflavon mencegah oksidasi LDL, sehingga banyak LDL ditangkap oleh sel hati, sehingga kolesterol total ikut turun. Semakin rendah foam cell, maka resiko terjadinya aterosklerosis menurun, sehingga isoflavon disebut juga kardioprotektif. Beberapa penelitian yang menunjukkan bahwa asupan kedelai dapat menurunkan absorbsi langsung kolesterol dan TG di usus, sehingga kadar kolesterol ester dan TG menurun. Hal ini pula mengakibatkan penurunan kadar kolesterol total dalam darah (Yousef, 2004).

Penurunan kadar kolesterol total yang diteliti bervariasi, tergantung faktor dan perlakuan 
penelitian. faktor dan perlakuan tersebut diantaranya adalah bentuk dan jenis isoflavon, kadar asupan isoflavon, waktu penelitian, gender dari subjek, kadar lipid serta status dari menopause.

Bentuk isoflavon yang sudah diteliti adalah ISP (Isolate Soy Protein), tablet isoflavon, kapsul protein kedelai, biskuit kedelai, burger kedelai, susu kedelai dan tempe. Konsumsi isoflavon sebagai ISP mengakibatkan perbaikan signifikan dalam kadar kolesterol total pada wanita postmenopause normoklesterolemi dan agak hiperkolesterolemia (Wangen, 2001; Mackey, 2000). Ini disebabkan karena ISP merupakan salah satu sumber isoflavon yang besar yaitu sebanyak 100 miligram isoflavon dalam 100 gram (Tabel 2.2) (Astawan, 2009).

Bentuk yang lain dari isoflavon adalah tablet isoflavon. Dalam satu tablet isoflavon mengandung daidstein, genistein, biochanin, formononectin atau berisi daidstein dan genistein atau hanya berisi genistein saja. Daidstein, genistein, biochanin, formononectin adalah macam dari isoflavon. Dari hasil penelitian mengenai bentuk tablet isoflavon menunjukkan bahwa tablet Isoflavon, sampai $150 \mathrm{mg}$ per hari, memiliki efek signifikan dalam menurunkan serum kolesterol total, LDLkolesterol dan trigliserida. Ada juga manfaat signifikan atas serum HDL-kolesterol. Hasilnya konsisten ketika tablet diperkenalkan sebagai genistein terisolasi saja, tetapi pada campuran genistein dan daidzein, atau campuran genistein, daidzein, formononectin dan biochanin tidak memberikan efek yang signifikan yang ditemukan antara peserta dengan hiperlipidemia normo-atau dan wanita dengan status pre-atau postmenopause. Hal ini diduga masing-masing komposisi gabungan isoflavon saling mempengaruhi sehingga memberi hasil yang tidak signifikan (Clifton-Bligh, 2001; Dewell, 2002; Hale, 2002; Squadrito, 2002).

Han (2002) meneliti manfaat isoflavon kedelai dengan kapsul protein kedelai (isoflavon 100 miligram). Studi tersebut memberikan hasil yang tidak terlalu signifikan terhadap penurunan kadar kolesterol total. Sehingga kapsul protein kedelai dianggap sebagai alternatif saja dari terapi kardioprotektif.

Biskuit dan burger kedelai dinilai merupakan produk yang menarik konsumen, karena rasa lebih enak dan kemasannya lebih menarik. Protein kedelai isoflavon rendah dan tinggi konsentrat mengandung isoflavon 698 dan $548 \mathrm{~g}$ protein $/ \mathrm{kg}$. Protein kedelai bertekstur dibuat menjadi burger vegetarian, dan subjek diminta untuk mengkonsumsi satu burger tiap hari selama masa studi. Calvert (1981), telah meneliti tentang kandungan dan manfaat dari biskuit kedelai. Dari hasil penelitiannya, menunjukkan hampir signifikan dalam penurunan kadar kolesterol dalam darah. Tetapi sebaliknya, burger kedelai menunjukkan hasil tidak signifikan dalam penurunan kolesterol total dalam darah pada uji coba pria dan wanita, diduga dikarenakan proses pemanasan burger kedelai yang mengakibatkan hilangnya sebagian protein penting dan juga kontaminasi kolesterol pada minyak penggorengan (Sanders, 2002).

Dari sebuah meta analisis dari 17 studi oleh Yeung (2003), menunjukkan bahwa kadar asupan isoflavon $(<50 \mathrm{gr} / \mathrm{hr}$; $51-100 \mathrm{gr} / \mathrm{hr}$; dan 101$150 \mathrm{gr} / \mathrm{hari}$ ) tidak begitu berpengaruh terhadap penurunan kolesterol total. Hal ini diduga isoflavon terutama genistein yang berikatan terhadap reseptor estrogen memiliki afinitas yang rendah (Miksicek, 1994), selain itu isoflavon harus berkompetisi dengan estrogen endogen terhadap reseptor estrogen. Waktu perlakuan juga berpengaruh pada kadar kolesterol total pada asupan isoflavon. Waktu perlakuan 11-20 minggu memberikan hasil yang signifikan di bandingkan dengan 2-10 minggu, hal ini diduga adanya waktu adaptasi hingga mencapai afinitas tertentu terhadap reseptor estrogen, sedangkan waktu perlakuan 2130 minggu memberikan hasil yang tidak signifikan. Ini diduga karena pada masa 21-30 merupakan akhir dari durasi isoflavon di dalam darah yang selanjutnya akan diekskresikan melalui ginjal (Squadrito, 2002; Urban, 2001; Samman, 1999; Sanders, 2002; Nestel, 1999; Han, 2002; Mackey, 2000).

Pengaruh gender ternyata berpengaruh terhadap kadar kolesterol total pada asupan isoflavon. Seorang laki-laki mengalami penurunan kolesterol total yang lebih signifikan dibandingkan perempuan. Ini diduga karena isoflavon pada wanita harus bersaing dengan estrogen endogen yang kadarnya lebih tinggi dibandingkan estrogen endogen pada laki - laki. Hal ini terkecuali pada variabel wanita dengan status peri- atau post menopause (hipoesterogen) (Sanders 2002; Hodgson 1998).

Data meta analisis menunjukkan bahwa, studi asupan kedelai terhadap penurunan kadar kolesterol total pada subjek normokolesterol lebih signifikan dibandingkan dengan subjek dengan hiperlipidemi pada laki-laki. Tetapi masih belum diketahui sebab dari penurunan kolesterol total lebih signifikan pada orang dengan normokolesterol. Serta menunjukkan penurunan kadar kolesterol total dengan status postmenopause lebih signifikan dibandingkan 
dengan status pre- dan perimenopause, dan perimenopause lebih signifikan dibandingkan dengan premenopause. Hal ini disebabkan oleh karena kadar estrogen pada masa perimenopause lebih sedikit dibandingkan dengan pada masa premenopause serta pada masa postmenopause, kadar estrogennya lebih sedikit dibandingkan dengan peri- dan premenopause. Kadar estrogen pada masa postmenopause bisa mencapai angka yang sangat rendah sehingga gejala vasomotor dan urogenital lebih sering dikeluhkan. Oleh sebab itu terapi pengganti estrogen endogen sangat dibutuhkan untuk mengurangi keluhan tersebut. Salah satu cara untuk mengurangi keluhan tersebut dengan mengkonsumsi senyawa isoflavon pada kedelai (Yeung, 2003).

Selain faktor yang sudah dijelaskan diatas, Perlu dipertimbangkan juga beberapa faktor yang belum ditemukan atau diteliti. Faktor tersebut yaitu berat badan dan distribusi lemak, asupan protein lain, dan aktifitas fisik yang mungkin berpengaruh dalampenurunan kolesterol total dalam darah.

\section{DAFTAR PUSTAKA}

Adam, John, 2006, Dislipidemia, in: Aru W, Sudoyo, Setiyohadi bambang, Imm Penyakit Dalam Jilid 3, edisi 4, Pusat Penerbitan Departemen Ilmu Penyakit Dalam FK-UI, Jakarta, pp. 1926-1928

Aso T, 1999, Demogrgaphy of the menopause and pattern of climacteric symtoms in the East Asian region, viewed: 12 august 2010

(http://www.gfmer/books/book $\mathrm{mp} / 24 . \mathrm{htm})$

Astawan, Made, 2009, Sehat Dengan Hidangan Kacang dan Biji-bijian, Penebar Swadaya, Jakarta

Avis NE, 2001, Is trere a Menopauseal Syndrome? Menopausal Status and symptoms across raciall ethnic groups, Soc Sci Med, Vol.52, pp. 56-354

Calvert GD, 1981, A trial of the effects of soya-bean flour and soya-bean saponins on plasma lipids, faecal bile acids and neutral sterols in bypercholesterolaemic men. Br J Nutr, Vol.45, pp.277-281.

Cassidy A, 2006, Factors affecting the bioavailability of soy isoflavones in bumans after ingestion of physiologically relevant levels from different soy foods. J Nutr, Vol.136, pp.45-51.

Chavarro JE, 2008, Kedelai makanan dan asupan isoflavon dalam bubungannya dengan parameter kualitas air mani antara manusia dari sebuah klinik infertilitas, Jhavarr Hum Reprod, Vol.23 (11), pp.90-2584

Clifton-Bligh PB, 2001, The effect of isoflavones extracted from red clover (Rimostil) on lipid and bone metabolism. Menopause, Vol.8(4), pp.259265.

Dennerstein L, 2000, A Prospective Population-based, study of menopausal symtoms, Obset Gynecol, Vol. 96, pp. 8-351

Despopoulos, Agamemnon, 2000, Atlas berwarna \& teles Fisiologi, Hipokrates, Jakarta

Dewell A, 2002, The effects of soy-derived phytoestrogens on serum lipids and lipoproteins in moderately bypercholesterolemic postmenopausal women. J Clin Endocrinol Metab, Vol.87, pp.118-121

Enmark E, Pelto-Huikko M, Grandien K, et al, 1997, Human estrogen receptor b-gene structure, chromosomal localization, and expression pattern, $\mathrm{J}$ Clin Endocrinol Metab, Vol.82, pp.65-4258

Fajriah, Novita, 2009, Pengaruh Susu Kedelai Terhadap Kadar Kolesterol Darah Tikus Jantan Galur Wistar (Rattus norvegicus L.) yang Dikondisikan Mengalami Hiperlipidemia, Program Studi Sarjana Biologi SITH, Institut Teknologi Bandung

Gold EB, 2000, Relation of Demographic and Lifestyle Factors to Symptoms in a Multi-raciall Etnic Population of Women 40-55 years of age, Am. J. Epidemiol, Vol.152, pp. 73- 463

Grady, Deborah, 2006, Management of Menopausal Symtoms, The New England Journal of Medicine, Vol. 355, pp. 23-38

Gruber, Cristian J, 2002, Production and Action of Estrogen, The New England Journal of Medicine, vol. 346, viewed: 3 juni 2010 (http://www.nejm.org/cgi/reprint/346/5/3 40)

Guyton CA, Hall EJ, 2006, Buku Ajar Fisiologi Kedokteran edisi 9, EGC, Jakarta

Hale G, 2002, Isoflavone supplementation and endothelial function in menopausal women, Clin Endocrinol, Vol.56, pp.693-701

Han KK, 2002, Benefits of soy isoflavone therapeutic regimen on menopausal symptoms. Obstet Gynecol, Vol.99, pp.389-394.

Harborn JB, 2000, Metode Fitokimia Penuntun Cara Modern Menganalisis Tumbuban, ITB, Bandung

Hidayat A, 2003, Identifikasi dan Isolasi Isoflavon Non Kedelai Tumbuban Polong, in: Simposium Nasional Persatuan Menopause Indonesia dan asia Pasifik, Jakarta, Agustus, pp. 1-10

Hodgson JM, 1998, Supplementation with isoflavonoid phytoestrogens does not alter serum lipid concentrations: a randomized controlled trial in bumans, J Nutr, Vol.128, pp.728-732.

Iafrati MD, Karas RH, Aronovitz M, et al, 1997, Estrogen inbibits the vascular injury response in estrogen receptor alpha-deficient mice, Nat Med, Vol.3, pp.8-545 
Koswara, Sutrisno, 2009, Isoflavon, Senyawa Multi Manfaat Dalam Kedelai, viewed : 16 September 2009) (http://www.Organicindonesia.org)

Kuiper GG, Lemmen JG, Carlsson B, et al, 1998, Interaction of estrogenic chemicals and phytoestrogens with estrogen receptor b, Endocrinology, Vol.139 63-4252

Mackey R,2000, The effects of soy protein in women and men with elevated plasma lipids. Biofactors, Vol.12, pp.251-257.

Mark, Dawn B, 2000, Biokimia Kedokteran Dasar, EGC, Jakarta

Murray K, David A Bender, Kathleen M. Botham, Peter J. Kennelly, Victor W. Rodwell, P. Anthony Weil, 2009, Harper's Illustrated Biochemistry $28^{\text {th }}$ edition, The McGraw-Hill Companies, pp:853-889

NCEP ATP III, 2001, Executive Summary of the Third Report of the NCEP ATP III, JAMA, Vol 285, pp. 2486-2497

Nelson HD, 2005, Management of Menopause-related Symtoms, Agency for Healtcare Research and Quality, Vol.5, pp. 2-16

Nilson S, 2000, Transactivation Basic Aspect of Estrogen Action, Breast Ca, Vol 2, pp. 360366

Practice Committee of The American Society for Reproductive Medicine, 2008, Estrogen and Progesteron therapy in postmenopausal Women, TASM, Vol.90, pp.88-102

Samman S, 1999, The effect of supplementation with isoflavones on plasma lipids and oxidisability of low density lipoprotein in premenopausal women, Atherosclerosis, Vol.147, pp.277-283

Sanders TAB, 2002, Moderate intakes of intact soy protein rich in isoflavones compared with ethanolextracted soy protein increase HDL but do not influence transforming growth factor beta concentrations and bemostatic risk factors for coronary heart disease in healthy subjects. Am J Clin Nutr, Vol.76, pp.373-377.

Setchell, Kenneth D R;Cassidy, Aedin, 1999, The Journal of Nutrition; Mar 1999; 129, 3; ProQuest Agriculture Journals pg. S758

Supriyanto, 2006, Pengaruh Pemberian Ekstrak Kedelai Terbadap Kadar Kolesterol,LDL, HDL, dan Rasio LDL/HDL Darab Tikus Putib jantan (Rattus norvegicus)yang mengalami Hiperkolesterolemia, Universitas Airlangga, Surabaya

Soewondo, Pradana, 2006, Menopause, Andropause dan Somatopause Perubahan Hormonal pada Proses Menua, in: Aru W, Sudoyo, Setiyohadi bambang, Ilmu Penyakit Dalam Jilid 3, edisi 4,
Pusat Penerbitan Departemen Ilmu Penyakit Dalam FK-UI, Jakarta, pp. 1989-1992

Squadrito F, 2002, The effect of the phytoestrogen genistein on plasma nitric oxide concentrations, endothelin-1 levels and endothelium dependent vasodilation in postmenopausal women, Atherosclerosis, Vol:163, pp.339-347

USDA-Iowa State University, 2002, Database Konten isoflavon Makanan, USDA, Vol, pp. 1-3

Yeung, john, 2003, Effects of isoflavones (soy phytoestrogens) on serum lipids: a meta-analysis of randomized controlled trials, NJ, vol.2, pp.1-15

Yousef. Mokhtar I, 2004, Antioxidant activities and lipid lowering effects of soflavone in male rabbits, Food and Chemical Toxicology, vol.42, pp. 1497-15 